\title{
Efek Red Wine Terhadap Kesehatan Kardiovaskular
}

\author{
Thalia W. Malingkas, ${ }^{1}$ Stefana H.M. Kaligis, ${ }^{2}$ Murniati Tiho ${ }^{2}$
}

\author{
1Program Studi Pendidikan Dokter Fakultas Kedokteran Universitas Sam Ratulangi, \\ Manado, Indonesia. \\ ${ }^{2}$ Bagian Biokimia Fakultas Kedokteran Universitas Sam Ratulangi, Manado, Indonesia \\ Email: thaliawanny@yahoo.com
}

\begin{abstract}
Many studies showed that antioxidants contained polyphenols and flavonoids such as red wine could reduce the risk of cardiovascular disease. This study's purpose is to determine the effect of red wine on cardiovascular health. This is a literature review using three databases: Pubmed, Google Scholar and Clinical Key. The keywords using to search the articles are red wine AND cardiovascular disease AND antioxidant OR antioksidan AND flavonoid. After being selected based on inclusion and exclusion criteria, ten literatures were found. The research methods using in the literatures were very varied, which were a cross-over study, single blind cross-over, double-blinded, comprised two study days, parallel four-armed intervention, experimental, randomized, and prospective study. The subjects in these studies were also varied, from healthy people to people with cardiovascular disorders and with other health problems. Besides red wine, interventions with dealcoholized red wine and red grape polyphenol extract (RGPE) also were used in some studies. However, the results from all studies showed that consuming red wine has a good effect on cardiovascular health, measured from LDL and HDL blood level, FMD and systolic blood pressure. In conclusion, red wine consumption has beneficial effects on cardiovascular health.
\end{abstract}

Keywords: red wine, antioxidant, cardiovascular health, polyphenol, flavonoid

\begin{abstract}
Abstrak: Banyak penelitian menunjukkan bahwa antioksidan yang mengandung polifenol dan flavonoid seperti red wine dapat menurunkan risiko penyakit kardiovaskular. Tujuan penelitian ini untuk mengetahui efek red wine terhadap kesehatan kardiovaskular. Penelitian ini berbentuk literature review menggunakan tiga database yaitu Pubmed, Google Scholar, dan Clinical Key. Kata kunci yang digunakan dalam pencarian artikel yaitu red wine AND cardiovascular disease AND antioxidant OR antioksidan AND flavonoid. Setelah diseleksi berdasarkan kriteria inklusi dan eksklusi, didapatkan 10 literatur yang memenuhi kriteria. Literatur-literatur yang ditemukan menggunakan metode penelitian beragam yaitu cross-over study, single blind cross-over, double-blinded, comprised two study days, parallel four-armed intervention, experimental, randomized, dan prospective study. Subjek yang berpartisipasi dalam studi-studi tersebut juga bervariasi, yaitu terdiri dari orang yang sehat, orang dengan ganguan kardiovaskular dan orang dengan gangguan kesehatan lainnya. Selain red wine, intervensi menggunakan dealcoholized red wine, dan red grape polyphenol extract (RGPE) juga dilakukan pada beberapa studi. Meskipun demikian, hasil yang didapatkan dari semua studi menunjukkan bahwa mengonsumsi red wine memberikan efek yang baik terhadap kesehatan kardiovaskular, yang dilihat dari pengukuran LDL dan HDL darah, FMD dan systolic blood pressure. Sebagai simpulan konsumsi red wine memberikan efek yang bermanfaat bagi kesehatan kardiovaskular.
\end{abstract}

Kata Kunci: red wine, antioksidan, kesehatan kardiovaskular, polifenol, flavonoid

\section{PENDAHULUAN}

Penyakit kardiovaskular merupakan penyebab kematian nomor satu di dunia dan lebih banyak orang meninggal setiap tahun karena penyakit kardiovaskular dibandingkan akibat penyebab lainnya. 
Menurut data dari World Health Organization (WHO) pada tahun 2016 terdapat sekitar 17,9 juta kematian karena penyakit kardiovaskular, dan hal tersebut mewakili $31 \%$ kematian di seluruh dunia. Dari kematian tersebut, $85 \%$ disebabkan oleh serangan jantung dan stroke. ${ }^{1}$

Berdasarkan data Riset Kesehatan Dasar (Riskesdas) tahun 2018, angka kejadian penyakit jantung dan pembuluh darah semakin meningkat dari tahun ke tahun. Terdapat 15 dari 1000 orang atau sekitar 2.784.064 individu di Indonesia menderita penyakit jantung. Data Riset Kesehatan Dasar 2018 juga menunjukkan prevalensi Penyakit Jantung di Indonesia sebesar $1.5 \%$ dengan peringkat prevalensi tertinggi yaitu provinsi Kalimantan Utara $2.2 \%$, DI Yogyakarta 2\% dan Gorontalo $2 \%{ }^{2}$

Penyakit kardiovaskular terjadi oleh karena ada gangguan fungsi jantung dan pembuluh darah. Terdapat banyak macam penyakit kardiovaskular, namun yang paling umum dan paling terkenal ialah penyakit jantung koroner dan stroke. ${ }^{3}$ Penyakit jantung koroner terjadi karena aterosklerosis dan perkembangannya terkait dengan faktor lingkungan dan genetik. ${ }^{4}$

Terdapat beberapa penelitian yang telah menyimpulkan bahwa dengan mengonsumsi alkohol dalam jumlah sedang dapat menyebabkan penurunan risiko penyakit jantung koroner. $^{5-7}$ Asupan etanol dari semua jenis minuman beralkohol bermanfaat, tetapi mengonsumsi red wine dapat memberikan manfaat kesehatan tambahan. ${ }^{8}$

Red wine merupakan minuman beralkohol terkenal yang telah dikonsumsi selama ratusan tahun. Red wine mengandung berbagai macam senyawa aktif dengan sifat antioksidan. ${ }^{9}$

Penelitian Dellagli tahun 2004, tentang komposisi anggur merah yang difokuskan pada kandungan polifenol yang terkandung dalam anggur merah dan sifat antioksidannya, ditemukan bahwa anggur mengandung sangat banyak polifenol. ${ }^{10}$ Aktivitas polifenol dalam hal mengurangi risiko penyakit kardiovaskular telah banyak diteliti. Hasilnya menunjukkan bahwa manfaat polifenol bermanfaat terhadap fungsi jantung, mengurangi risiko penyakit kardiovaskular, aterosklerosis, serangan jantung, serta penurunan risiko hipertensi dan diabetes. ${ }^{5-7,11}$

Polifenol memiliki efek positif pada fungsi jantung dan pencegahan penyakit kardiovaskular, $^{12}$ dengan memodulasi mekanisme seluler dan molekuler yang mengarah pada respons antiinflamasi dan antioksidan. ${ }^{13}$ Polifenol pada red wine juga akan meningkatkan produksi NO yang akan menginduksi vasodilatasi. ${ }^{14}$

Tujuan penelitian ini yaitu untuk mengetahui efek red wine terhadap kesehatan kardiovaskular.

\section{METODE PENELITIAN}

Penelitian ini merupakan penelitian deskriptif yang berbentuk literature review yang dilakukan dengan cara identifikasi, evaluasi dan interpretasi terhadap semua hasil penelitian tertentu, topik tertentu atau fenomena yang menjadi perhatian. Literature review adalah metode penelitian yang merangkum hasil-hasil penelitian primer untuk menyajikan fakta yang lebih komprehensif. Data yang digunakan dalam penelitian ini ialah data sekunder yang diperoleh bukan dari pengamatan langsung. Data sekunder diperoleh dari hasil penelitian, artikel dan jurnal ilmiah bereputasi baik nasional maupun internasional dengan tema yang sudah ditentukan. Kata kunci yang digunakan dalam pencarian artikel yaitu red wine AND cardiovascular disease AND antioxidant OR antioksidan AND flavonoid.

\section{HASIL PENELITIAN}

Berdasarkan pencarian literatur melalui 3 database elektronik, peneliti mendapatkan artikel sebanyak 220 menggunakan Pubmed, 13.599 menggunakan Clinical Key dan 32.700 menggunakan Google Scholar $(\mathrm{n}=46.519)$. Setelah dilakukan pencarian, disesuaikan dengan kriteria inklusi dan eksklusi, kemudian dieksklusi. Hasil seleksi akhir didapatkan 10 literatur yang memenuhi kriteria dan lolos tahap seleksi (Tabel 1). 
Tabel 1. Ringkasan penelusuran literatur

\begin{tabular}{|c|c|c|c|c|}
\hline $\begin{array}{l}\text { Penulis, } \\
\text { Tahun }\end{array}$ & $\begin{array}{l}\text { Metode } \\
\text { Penelitian }\end{array}$ & Population & $\begin{array}{l}\text { Intervention/ } \\
\text { comparator }\end{array}$ & Outcomes \\
\hline $\begin{array}{l}\text { Apostolidou } \\
\text { et al, } 2015^{15}\end{array}$ & $\begin{array}{l}\text { Cross-over } \\
\text { study }\end{array}$ & $\begin{array}{l}21 \text { pria } \\
\text { dan } 19 \\
\text { wanita }\end{array}$ & $\begin{array}{l}\text { Dibagi menjadi } 2 \\
\text { kelompok yang } \\
\text { disesuaikan dengan usia } \\
\text { menurut kadar kolesterol } \\
\text { totalnya: (1) } \\
\text { Asymptomatic } \\
\text { Hypercholesterolemics } \\
\text { (AHC), (2) } \\
\text { Normocholesterolemics } \\
\text { (NC). }\end{array}$ & $\begin{array}{l}\text { Hasil penelitian Total } \\
\text { antioxidant capacity (TAC) } \\
\text { meningkat secara signifikan } \\
\text { setelah intervensi pada semua } \\
\text { subjek pada kelompok AHC dan } \\
\text { NC dengan perbedaan rata-rata } \\
\text { (post-pre) } 1,78 \text { mmol/L dan } 0,87 \\
\text { mmol/L. vitamin E meningkat } \\
\text { signifikan terutama pada } \\
\text { kelompok AHC (peningkatan } \\
13,1 \% \text { dibandingkan kelompok } \\
\text { NC }(5,41 \% \text { ) setelah konsumsi } \\
\text { red wine, dengan peningkatan } \\
\text { yang lebih tinggi pada kelompok } \\
\text { AHC. Terdapat efek pengobatan } \\
\text { marginal yang signifikan } \\
\text { (penurunan) pada rasio } \\
\text { LDL/HDL puasa (p = 0.05) dan } \\
\text { peningkatan yang signifikan } \\
\text { secara statistik pada rasio } \\
\text { vitamin E/TC relatif terhadap } \\
\text { minum plasebo untuk NC (p < } \\
\text { 0.005) dan pada kelompok AHC } \\
\text { (p < 0.002). }\end{array}$ \\
\hline $\begin{array}{l}\text { Karatzi, et } \\
\text { al, } 2004^{16}\end{array}$ & $\begin{array}{l}\text { Double- } \\
\text { blinded, } \\
\text { cross-over, } \\
\text { dan } \\
\text { comprised } \\
\text { two study } \\
\text { days }\end{array}$ & $\begin{array}{l}15 \text { pria } \\
\text { dengan } \\
C A D\end{array}$ & $\begin{array}{l}\text { Semua relawan } \\
\text { diberikan } 250 \mathrm{ml} \text { de- } \\
\text { alcoholized red wine } \\
\text { pada } 2 \text { hari yang } \\
\text { berbeda }\end{array}$ & $\begin{array}{l}\text { Secara keseluruhan, konsumsi } \\
\text { dealcoholized red wine } \\
\text { menghasilkan respons FMD } \\
\text { yang lebih tinggi daripada } \\
\text { regular red wine (efek jenis } \\
\text { anggur, } \mathrm{p}=0,05 \text { ). Terdapat juga } \\
\text { jenis wine yang signifikan } \\
\text { berdasarkan pengaruh interaksi } \\
\text { waktu ( } \mathrm{p}=0.006 \text { ), yang } \\
\text { menunjukkan bahwa pola } \\
\text { respon FMD berbeda antara } \\
\text { kedua wine tersebut. }\end{array}$ \\
\hline $\begin{array}{l}\text { Hansen, et } \\
\mathrm{al}, 2005^{17}\end{array}$ & $\begin{array}{l}\text { A parallel } \\
\text { four-armed } \\
\text { intervention } \\
\text { study }\end{array}$ & $\begin{array}{l}69 \text { orang } \\
\text { umur } \\
38-74 \\
\text { tahun } \\
\text { pria dan } \\
\text { wanita }\end{array}$ & $\begin{array}{l}\text { Subjek diacak menjadi: } \\
\text { (1) red wine (pria: } \\
\text { 300ml/hari, } 38.3 \mathrm{~g} \\
\text { alkohol/hari, subjek } \\
\text { wanita: } 200 \mathrm{ml} / \mathrm{hari}, \\
25.5 \mathrm{~g} \text { alkohol/hari). (2). } \\
\text { air + tablet ekstrak red } \\
\text { wine (dosis setara } \\
\text { wine). (3) tablet ekstrak } \\
\text { air }+ \text { red wine (setengah } \\
\text { dosis) (4) air + tablet } \\
\text { plasebo untuk jangka } \\
\text { waktu } 4 \text { minggu. }\end{array}$ & $\begin{array}{l}\text { Konsumsi wine dikaitkan } \\
\text { dengan peningkatan signifikan } \\
\text { pada HDL-C puasa } 11-16 \% \text { dan } \\
\text { penurunan fibrinogen puasa } \\
\text { sebesar } 8-15 \% \text { dibandingkan } \\
\text { dengan tidak minum wine. } \\
\text { Tidak ada efek pengobatan yang } \\
\text { signifikan pada puasa LDL-C, } \\
\text { rasio HDL-C/LDL-C-C, VLDL- } \\
\text { triasilgliserol, kolesterol total, } \\
\text { FVIIc, atau tekanan darah. }\end{array}$ \\
\hline
\end{tabular}


Filho, et al, Experimental 32 $2010^{18}$

$\begin{array}{lll}\text { Whelan, et } & \text { Randomized, } & 14 \text { pria } \\ \text { al, 2003 }{ }^{19} & \begin{array}{l}\text { prospective, } \\ \text { single blind } \\ \text { cross-over } \\ \text { trial }\end{array} & \begin{array}{l}30-70 \\ \text { tahun }\end{array}\end{array}$

Lekakis, et al, $2005^{20}$
Dibagi menjadi 4 spontan kelompok: wine dan eously hyperten sive Rats (SHR) trial exercise group (WEG), wine group (WG), exercise group (EG) dan control group (CG). Dosis red wine diberikan secara intragastric, selama 10 minggu, bertepatan dengan periode physical exercise (PE), dilakukan pada treadmill. SHRs menerima dosis red wine $3.715 \mathrm{ml} / \mathrm{kg} / \mathrm{hari}$.

Mengonsumsi white wine dan red wine
Hasil penelitian menunjukkan bahwa tiga kelompok yang mengalami intervensi menunjukkan penurunan systolic blood pressure (SBP) yang signifikan dibandingkan dengan CG. Di akhir protokol, WEG menunjukkan penurunan terbesar. Seperti dalam hasil SBP, WEG menunjukkan hasil terbaik pada tingkat HDL di akhir percobaan. Tidak ada perbedaan signifikan antara kinerja fisik dan LVEF antar kelompok.

Pada baseline, FMD serupa (white wine 1,6 $\pm 1,9 \%$, red wine $1,8 \pm 1,7 \%$ ). Pada 360 menit setelah konsumsi wine tidak ada perbedaan dalam FMD, yang meningkat hampir tiga kali lipat setelah kedua wine (white wine $4,7 \pm 2,2 \%$, red wine $3.4 \pm 2.9 \% ; \mathrm{p}=0,002$ ). Tidak ada perubahan yang terdeteksi dalam kadar polifenol plasma setelah wine.

Asupan ekstrak polifenol red wine menyebabkan peningkatan dilatasi yang dimediasi aliran memuncak pada 60 menit yang secara signifikan lebih tinggi dari nilai baseline $(4,52 \pm 1,34$ versus $2,6 \pm 1,5 \%$; $p<0,001)$ dan nilai yang sesuai pada 60 menit setelah asupan plasebo $(4,52 \pm 1,34$ versus $2,64 \pm 1,8 \%$, $\mathrm{p}<0,001)$. Tidak ada perubahan nilai FMD setelah asupan plasebo selama penelitian berlangsung.

Tekanan darah sistolik perifer tetap tidak berubah pada kedua minuman, sedangkan penurunan tekanan darah diastolik perifer dan sentral yang signifikan diamati setelah konsumsi dealcoholized red wine $(\mathrm{p}=.03$ dan $\mathrm{p}=.035$, masing-masing). Tekanan darah sistolik sentral menurun setelah konsumsi teratur $(-7.4 \pm 2.4 \mathrm{mmHg}, \mathrm{P}=$ $.05)$ dan dealcoholize red wine $(-5.4 \pm 2.7 \mathrm{mmHg}, \mathrm{P}=.019)$. 
Ceriello, et Experimental 20 orang Dibagi menjadi tiga al, $2001^{22}$

Guarda, et al, $2005^{23}$ dengan

diabetes

tipe 2 studi berbeda dalam urutan acak pada hari yang berbeda: tes makan standar, konsumsi red wine $300 \mathrm{ml}$ dengan puasa, dan makan ditambah $300 \mathrm{ml}$ red wine.
Glukosa plasma, insulin, trigliserida, dan oksidasi LDL meningkat secara signifikan, sedangkan parameter plasma radical-trapping menurun secara signifikan selama tes makan. Konsumsi red wine dalam keadaan puasa secara signifikan meningkatkan aktivitas parameter total plasma radical-traping, sementara konsumsi wine dengan makanan mengimbangi penurunan parameter total plasma radical-trapping dan peningkatan oksidasi LDL.

Konsumsi makanan menginduksi peningkatan fragmen prothrombin plasma $1+2$ dan mengaktifkan faktor VII pada pasien diabetes. Konsumsi wine dengan makanan secara signifikan mengurangi produksi kedua fragmen prothrombin $1+2$ dan faktor VII yang diaktifkan. Konsumsi red wine saat puasa saja tidak menunjukkan efek pada koagulasi atau oksidasi LDL.

Rasio dilatasi bergantung/ independen endotel meningkat secara signifikan dibandingkan dengan baseline pada kedua kelompok. Kandungan 8-OH deoxyguanosine menurun secara signifikan pada kedua kelompok; efek ini lebih terasa dengan wine ( $\mathrm{p}<0.002$ vs kotrol). Kerusakan asam deoksiribonukleat oksifatif pada kontrol menurun dari 13.1 \pm 1.1 to $10.0 \pm 1.0(\mathrm{p}<0.003)$; dengan wine dari $13 \pm 0.8$ ke 5.6 +0.7 per $10^{5}$ guanosin $(\mathrm{p}<0.001$; $\mathrm{p}<0.002$ vs kontrol). Reaktivitas antioksidan total meningkat dari $240 \pm 18$ ke $18 \mu \mathrm{M}$ pada kelompok kontrol dan dari $273 \pm$ 20 ke $330 \pm 15 \mu \mathrm{M}$ pada kelompok wine ( $\mathrm{p}<0.03$ vs kontrol). Kekuatan antioksidan pereduksi besi meningkat dari $1106 \pm 60 \mathrm{ke} 1235 \pm 42 \mu \mathrm{M}$ pada kelompok kontrol dan dari 1219 $+82 \mathrm{ke} 1450+63 \mu \mathrm{M}$ pada kelompok wine ( $\mathrm{p}<0.001)$ vs control. 
Avellone, Randomized 48 orang et al, 2005
Subjek dipilih secara acak dibagi menjadi dua kelompok yang ditugaskan menerima crossover design a Sicilian red wine selama makan: Kelompok A ( $\mathrm{n}$ $=24)$, yang dietnya ditambahkan selama 4 minggu dengan 250 $\mathrm{ml} /$ hari red wine, diikuti oleh 4 minggu ketika mereka Kembali ke asupan red wine biasa; dam Kelompok B ( $\mathrm{n}=$ 24) dimana asupan red wine biasa dipertahankan selama 4 minggu, diikuti oleh 4 minggu Ketika diet dilengkapi dengan $250 \mathrm{ml} /$ hari red wine.
Pada akhir periode asupan red wine, LDL/HDL, fibrinogen, faktor VII, protein plasma Crekatif dan LDL Ab teroksidasi menurun secara signifikan, sedangkan HDL-C, Apo A1, TGFb1, t-Pa, PAI dan plasma total kapasitas antioksidan meningkat secara signifikan.

\section{BAHASAN \\ Penilaian LDL dan HDL}

Terdapat lima literatur yang membahas mengenai efek konsumsi red wine terhadap kadar LDL serta HDL darah. Pada penelitian oleh Filho, et al yang dilakukan pada 32 spontaneously hypertensive rats (SHRs), hasil penelitian menunjukkan kadar HDL yang lebih tinggi pada kelompok tikus yang diberikan red wine dan latihan fisik dibandingkan dengan kelompok kontrol serta kelompok tikus dengan latihan fisik. ${ }^{18}$

Dua penelitian yang dilakukan pada orang yang sehat menunjukkan efek yang baik dari red wine terhadap kadar HDL darah. Pada penelitian Hansen, et al yang dilakukan pada 69 orang umur 38-74 tahun pria dan wanita, didapatkan bahwa konsumsi wine dikaitkan dengan peningkatan signifikan pada HDL-C puasa 11$16 \%$ dibandingkan dengan tidak minum wine. Tidak ada efek pengobatan yang signifikan pada puasa LDL-C, rasio HDLC/LDL-C-C, VLDL-triasilgliserol, kolesterol total, FVIIc, atau tekanan darah. Pada penelitian Avellone, et al yang dilakukan pada 48 orang sehat didapatkan bahwa, pada akhir asupan red wine, LDL/HDL menurun secara signifikan, sedangkan HDL-C meningkat secara signifikan.

Dua penelitian lain dilakukan pada orang dengan gangguan kesehatan juga menunjukkan efek yang baik dari pemberian red wine terhadap LDL dan HDL. Pada penelitian Apostolidou, et al yang dilakukan pada dua kelompok yaitu Asymptomatic Hypercholesterolemics (AHC) dan Normocholesterolemics (NC), evaluasi potensi risiko kardiovaskular, rasio LDL/HDL, diukur setelah satu bulan konsumsi red wine. Rasio LDL/HDL berkurang pada kelompok Asymptomatic Hypercholestrolemic (AHC) $(\mathrm{p}=0.05)$.

Pada penelitian Ceriello, et al yang dilakukan pada 20 orang dengan diabtes tipe 2, didapatkan bahwa konsumsi trigliserida dan oksidasi LDL meningkat secara signifikan. Konsumsi wine dengan makanan mengimbangi penurunan parameter total plasma radical-trapping dan peningkatan oksidasi LDL.

Red wine mempengaruhi kolesterol melalui beberapa mekanisme melalui polifenol dengan mempengaruhi kolesterol hati dan metabolisme lipoprotein. Mekanisme ini bekerja dengan mengurangi penyerapan kolesterol dan menurunkan 
pengiriman kolesterol ke hati yang mengurangi kolesterol plasma. Selain itu, polifenol mempengaruhi laju sekresi apolipoprotein B, memodifikasi partikel Very Low Density Lipoprotein (VLDL) dan mengurangi Trigliserida plasma (TG) karena kemungkinan peningkatan aktivitas Lipoprotein Lipase (LPL) yang menyebabkan penurunan LDL dalam sirkulasi. ${ }^{25}$ Temuan ini mendukung asumsi bahwa indeks ini dapat digunakan sebagai penanda prediktif yang relevan tentang efektivitas intervensi diet antioksidan untuk mengurangi faktor risiko kardiovaskular. ${ }^{15}$

Dibandingkan dengan antioksidan lain misalnya cathecins yang terdapat pada teh hijau, menunjukkan efek yang hampir sama dengan konsumsi red wine. Penelitian dari Gomikawa, et al pada wanita sehat menunjukkan penurunan kadar LDL dan kolesterol darah sesudah konsumsi teh hijau dalam dua minggu. ${ }^{26}$ Penelitian lain dari Hardani, et al pada wanita berusia 3555 tahun yang overweight dan obesitas, juga menunjukkan hasil penuruanan kadar LDL dan triasilgliserol (TAG) darah meskipun tidak signifikan dan meningkat kadar HDL secara signifikan. ${ }^{27}$

\section{Penilaian Flow mediated dilatation (FMD) dan fungsi endotel}

Terdapat empat literatur yang membahas mengenai FMD dan fungsi endotel. Pada penelitian oleh Karatzi, et al yang dilakukan pada 15 pria dengan Coronary Artery Disease (CAD), didapatkan bahwa konstituen selain alkohol meningkatkan FMD, tetapi dengan adanya semua konstituen ini termasuk polifenol bersama dengan alkohol mengganggu FMD. Penjelasan yang mungkin untuk hal ini adalah ketersediaan polifenol. Terdapat hasil kontroversial mengenai penyerapan polifenol, di satu sisi ada penelitian yang menunjukkan bahwa alkohol dalam red wine meningkatkan bioavailability dengan mengurangi presipitasi tannic acid, dan di sisi lain terdapat penelitian yang menunjukkan bahwa alkohol mengganggu penyerapan polifenol. Temuan pada penelitian ini dapat menunjukkan bahwa alkohol mungkin dapat mengganggu kerja polifenol, setidaknya selama 90 menit setelah konsumsi, tapi penelitian lebih lanjut diperlukan untuk mengkonfirmasi hipotesis ini. Secara keseluruhan, mempertimbangkan fakta bahwa konsumsi dua gelas regular red wine adalah bagian umum dari terapi nutrisi pasien CAD dan sirkulasi perifer yang dinilai pada penelitian ini terkait erat dengan fungsi endotel di arteri coroner. ${ }^{16}$

Pada penelitian oleh Whelan, et al yang dilakukan pada 14 pria umur $30-70$ tahun dengan CAD didapatkan bahwa pada baseline, FMD serupa sebelum pemberian minuman (white wine $1,6 \pm 1,9 \%$, red wine $1,8 \pm 1,7 \%$ ). Pada 360 menit setelah konsumsi wine tidak ada perbedaan dalam FMD, yang meningkat hampir tiga kali lipat setelah kedua wine (white wine 4,7 \pm $2,2 \%$, red wine $3.4 \pm 2.9 \% ; \mathrm{p}=0,002){ }^{19}$

Konsumsi dealcoholized red wine meningkatkan FMD pada 30-60 menit, kemungkinan dimediasi oleh antioksidan fenolik. FMD juga meningkat pada 120 menit setelah asupan red wine. Namun, dalam penelitian ini peningkatan FMD 6 jam pada pasien dengan CAD setelah minum red wine tampaknya tidak tergantung pada kandungan polifenol dalam wine. Besarnya peningkatan 6 jam FMD tidak terlalu berbeda setelah konsumsi red wine sebagai lawan dari white wine meskipun tingkat polifenol sekitar enam kali lebih tinggi dalam red wine. Selain itu, kadar polifenol plasma tidak meningkat dari baseline pada 6 jam setelah konsumsi red wine ketika FMD meningkat tajam. Tampaknya FMD diperbaiki dengan produk wine yang hadir dalam white wine (sauvignon blanc) dan red wine (pinot noir). ${ }^{19}$

FMD yang tidak berubah dan peningkatan diameter arteri pada 60 menit setelah asupan wine dalam penelitian ini tampaknya sesuai dengan hasil dari laporan sebelumnya. Dalam penelitian oleh Agewall et al, diameter dasar arteri brakialis meningkat dan FMD tidak berubah pada subjek sehat pada 30 menit 
dan 60 menit setelah konsumsi red wine. Sebaliknya, konsumsi dealcoholized red wine meningkatkan FMD dan tidak memengaruhi diameter arteri. Asupan alkohol tampaknya melebarkan arteri brakialis dan menutupi peningkatan FMD lebih awal setelah minum wine ${ }^{28,29}$. Jalur guanosin monofosfat siklik (GMP) mengatur dilatasi bergantung pada endotel dan yang diinduksi oleh glyceril trinitate (GTN). Dengan demikian, temuan dalam penelitian ini tentang penurunan dilatasi arteri brakialis yang diinduksi GTN dengan FMD yang tidak berubah pada 60 menit menunjukkan bahwa jalur GMP siklik mungkin tidak memediasi respons yang terganggu ini terhadap GTN. ${ }^{19}$

Pada penelitian oleh Lekakis, et al yang dilakukan pada 30 pria dengan PJK didapatkan bahwa asupan ekstrak polifenol red wine menyebabkan peningkatan dilatasi yang dimediasi aliran memuncak pada 60 menit yang secara signifikan lebih tinggi dari nilai baseline $(4,52 \pm 1,34$ versus 2,6 \pm $1,5 \%$; $<<0,001)$ dan nilai yang sesuai pada 60 menit setelah asupan plasebo $(4,52 \pm$ $1,34$ versus $2,64 \pm 1,8 \%, \mathrm{p}<0,001) .{ }^{20}$

Dalam penelitian ini peningkatan FMD dimulai 30 menit dan mencapai puncaknya 60 menit setelah konsumsi RGPE. Pola tindakan ini dapat dijelaskan dengan baik oleh penyerapan yang diusulkan oleh Goldberg et al yang menguji efisiensi absorpsi katekin, transveratrol, dan quercetin. Mereka menemukan bahwa konsentrasi senyawa ini (bebas dan terkonjugasi) ketika diberikan secara oral kepada subjek sehat memuncak dalam serum sekitar 30 menit setelah konsumsi. Penyerapan resveratrol adalah yang paling efisien dengan katekin yang terendah dan quercetin menengah ${ }^{30}$. Selanjutnya, durasi efek menguntungkan yang diamati dari RGPE pada endotel sesuai dengan laporan sebelumnya yang menunjukkan bahwa kapasitas antioksidan plasma maksimum biasanya mencapai 1-4 jam setelah konsumsi sumber polifenol. ${ }^{31}$

Pada penelitian oleh Guarda, et al yang dilakukan pada 20 orang dengan unstable angina atau non ST elevation myocardial infraction, didapatkan hasil penelitian menunjukkan bahwa konsumsi red wine dalam jumlah sedang sebagai suplemen untuk pengobatan standar pada pasien yang pulih dari sindrom koroner akut dapat ditoleransi dengan baik, dan menghasilkan peningkatan yang nyata pada fungsi endotel yang diukur sebagai rasio dilatasi yang bergantung pada endotelium/tidak bergantung pada endotelium. Peningkatan rasio ini lebih tinggi pada kelompok wine, tapi tidak mencapai signifikansi statistik. Pada temuan ini menunjukkan bahwa polifenol red wine dapat menghambat produksi ROS yang dapat menyebabkan kerusakan asam deoksiribonukleat oksidatif dan mendukung proses inflamasi. Selain itu, pengurangan stress oksidatif dan peningkatan fungsi endotel dapat bermanfaat pada pasien acute coronary syndrome. ${ }^{23}$

Efek red wine terhadap FMD dan fungsi endotel masih kurang baik bila dibandingkan dengan sumber antioksidan lain misalnya teh hijau. Hal ini dibuktikan dengan penelitian yang dilakukan oleh Alexopoulos, et al didapatkan bahwa FMD meningkat signifikan dengan teh (sebesar $3,69 \%$, puncak pada 30 menit, $\mathrm{P}<0.02)$. ${ }^{32}$ Pada penelitian oleh Lorenz, et al didapatkan bahwa FMD secara signifikan membaik setelah konsumsi teh hijau yang mengandung $200 \mathrm{mg}$ epigallocatechin 3gallate EGCG $(\mathrm{p}<0,01){ }^{33}$

Teh hijau jauh lebih baik karena dalam jangka pendek, yaitu 6 minggu, konsumsi teh dapat mengurangi hs-CRP. ${ }^{34}$ Teh hijau juga dapat merangsang produksi $\mathrm{NO}$ dalam sel endotel dengan mengaktifkan endothelial nitric oxide synthase (eNOS) dan menginduksi vasodilatasi di cincin aorta. $^{35}$

\section{Penilaian Systolic BP, Central dan Peripheral BP}

Terdapat dua literatur yang membahas mengenai Systolic BP, Central dan Peripheral BP. Pada penelitian oleh Paulo, et al yang dilakukan pada 32 spontaneously hypertensive rats (SHRs), didapatkan bahwa kedua kelompok tikus hipertensi 
yang menerima intervensi dalam isolasi baik kelompok exercise atau wine, menunjukkan penurunan tekanan darah sistolik. Pada model hewan SHR, kombinasi red wine dengan olahraga menunjukkan efek yang menguntungkan, yaitu menurunkan tekanan darah sistolik secara signifikan. Olahraga teratur menyebabkan serangkaian respons fisiologis akibat perubahan otonom dan hemodinamik yang akan memengaruhi sistem kardiovaskular. ${ }^{18}$

Pada penelitian oleh Karatzi et al yang dilakukan pada 15 orang dengan CAD, didapatkan bahwa meskipun tidak ada efek dari kedua wine yaitu red wine dan dealcoholized red wine pada tekanan darah perifer, efek signifikan pada tekanan darah sentral terbukti. Red wine dan dealcoholized red wine secara nyata mengurangi tekanan sistolik sentral. Fakta bahwa kedua minuman tersebut memiliki efek yang sama pada tekanan darah sistolik sentral menunjukkan bahwa efek ini dapat dikaitkan dengan antioksidan red wine terlepas dari kandungan alkoholnya. Fakta bahwa tekanan darah sistolik sentral menurun pada kedua kasus, sedangkan tekanan darah diastolik berkurang hanya setelah konsumsi dealcoholized red wine. Tekanan darah sentral pasien dengan CAD tampaknya membaik pada fase postprandial dengan konsumsi red wine, efek ini mungkin terkait tidak hanya dengan alkohol tapi juga dengan antioksidan red wine. $^{21}$

Dibandingkan dengan sumber antioksidan lain misalnya teh hijau, pemberian red wine menunjukkan efek yang hampir sama dengan konsumsi teh hijau. Penelitian meta-analisis yang dilakukan oleh Peng, et al menunjukkan konsumsi teh hijau secara signifikan menurunkan tekanan darah sistolik sebesar 21,98 mmHg. ${ }^{36}$ Mekanisme yang mendasari efek menguntungkan teh hijau pada pengendalian tekanan darah mungkin melibatkan beberapa aspek berikut: 1) Ekstrak teh hijau dapat mempertahankan tonus pembuluh darah dengan menyeimbangkan zat vasokonstriksi, termasuk angiotensin II, prostaglandin, endothelin-1 (ET-1), dan zat vasodilatasi seperti prostasiklin dan berbagai faktor hiperpolarisasi turunan endotel (EDHFs). 2) Teh hijau dapat meningkatkan fungsi ventrikel dan memberikan efek menguntungkan melalui peningkatkan produksi NO dari endotel pada jalur yang bergantung pada phosphoinositide-3-kinase (PI3). Ekstrak teh hijau juga mampu mengatur aktivasi eNOS dan produksi ROS, sehingga meningkatkan produksi NO. 3) Teh hijau mampu mengurangi stres oksidatif dan mengelola pembentukan ROS dengan menghambat enzim pro-oksidan dan menginduksi enzim antioksidan. Katekin teh hijau juga berfungsi menghambat nuclear factor-kappa $B$, redox-sensitive transcription factors, dan activator protein-1 yang bertanggung jawab atas stres oksidatif. Selain itu, katekin teh hijau dapat menginduksi efek antiinflamasi dengan menekan beberapa faktor inflamasi, seperti sitokin, molekul adhesi, dan nuclear factor-kappa $B .{ }^{36}$

Penelitian meta-analisis lain oleh $\mathrm{Xu}$, et al didapatkan bahwa konsumsi teh hijau menurunkan tekanan darah sistolik secara signifikan. ${ }^{37}$ Efek menguntungkan teh hijau pada kesehatan jantung mungkin terkait dengan konsentrasi tinggi katekin pada teh hijau. Katekin teh hijau memiliki banyak aktivitas biologis yang mungkin dapat memberikan manfaat antihipertensi, seperti: 1) Meningkatkan konsentrasi oksida nitrit plasma, yang dapat menghambat sitokin proinflamasi dan agregasi platelet dan menyebabkan perbaikan disfungsi endotel. 2) Menggunakan efek antiinflamasi melalui penekanan beberapa faktor inflamasi, seperti sitokin, nuclear factor-kappa $B$, dan molekul adhesi. 3) Menekan respon kontraktil dengan menghambat ekspresi mRNA dari nitrit oksida sintase dan endotelin-1 pada konsentrasi fisiologis, yang menghasilkan vasodilatasi dan penurunan tekanan darah berikutnya. 4) Meningkatkan sinyal kalsium dalam regulasi tingkat fosforilasi dari inositol triphosphate, calmodulin-dependent 
protein kinase II, calmodulin antibodies, terutama EGCG yang memiliki aktivitas antihipertensi yang kuat. ${ }^{37}$

Penelitian dalam bentuk literature review ini memiliki kelebihan dan kekurangan. Kelebihan dalam penelitian ini ialah tidak ditemukan literatur yang melakukan penelitian di Indonesia sehingga hasil penelitian literature review ini dapat dijadikan bahan dasar untuk penelitian selanjutnya khusunya di Indonesia. Kekurangan dalam penelitian ini ialah jumlah literatur yang direview masih sangat sedikit salah satunya karena hanya menggunakan tiga database karena keterbatasan waktu penelitian.

\section{SIMPULAN}

Berdasarkan kajian literature review disimpulkan bahwa terdapat efek yang bermanfaat bagi kesehatan kardiovaskular dengan mengonsumsi red wine. Red wine sebagai terapi alternatif untuk menjaga kesehatan kardiovaskular dapat menjadi topik menarik dalam penelitian lebih lanjut.

\section{Konflik Kepentingan}

Penulis menyatakan tidak terdapat konflik kepentingan dalam studi ini.

\section{DAFTAR PUSTAKA}

1. World Health Organization. Cardiovascular Disease. Available from: https://www.who.int/en/newsroom/fact-sheets/detail/cardio vascular-diseases-(cvds). 2017. Accessed on: September $8^{\text {th }} 2020$

2. Kemenkes RI. Hari Jantung Sedunia (World Heart Day). Available from: http://p2ptm.kemkes.go.id/ kegiatan-p2ptm/pusat-/hari-jan tung-sedunia-world-heart-dayyour-heart-is-our-heart-too. 2019. Accessed on: September $8^{\text {th }} 2020$

3. Kemenkes RI. Situasi Kesehatan Jantung. Available from: https:// www.kemkes.go.id/download.php ?file=download/pusdatin/infodatin /infodatin-jantung.pdf. 2014. Accessed on: September $8^{\text {th }} 2020$
4. Themistocleous I, Stefanakis M, Douda HT. Coronary Heart Disease Part I: Pathophysiology and Risk Factors. J Phys Act Nutr Rehabil. 2017;(April):167-75.

5. Rimm EB, Williams P, Fosher K, Criqui M, Stampfer MJ. Moderate alcohol intake and lower risk of coronary heart disease: Metaanalysis of effects on lipids and haemostatic factors. $\mathrm{Br}$ Med $\mathrm{J}$. 1999;319(7224):1523-28.

6. Jackson R, Scragg R, Beaglehole R. Alcohol consumption and risk of coronary heart disease. Br Med J. 1991;303(6796):211-6.

7. Tanasescu M, Hu FB, Willett WC, Stampfer MJ, Rimm EB. Alcohol consumption and risk of coronary heart disease among men with type 2 diabetes mellitus. J Am Coll Cardiol. 2001;38(7):1836-42.

8. Szmitko PE, Verma S. Antiatherogenic potential of red wine: Clinician update. Am J Physiol - Hear Circ Physiol. 2005;288(5):57-5).

9. Castaldo L, Narváez A, Izzo L, Graziani G, Gaspari A, Di Minno G, et al. Red wine consumption and cardiovascular health. Molecules. 2019; 24(19):1-20.

10. Liberale L, Bonaventura A, Montecucco F, Dallegri F, Carbone F. Impact of Red Wine Consumption on Cardiovascular Health. Curr Med Chem. 2017;26 (19):3542-66.

11. Snopek L, Mlcek J, Sochorova L, Baron M, Hlavacova I, Jurikova T, et al. Contribution of red wine consumption to human health protection. Molecules. 2018;23(7): 1-16.

12. Das S, Santani DD, Dhalla NS. Experimental evidence for the cardioprotective effects of red wine. Exp Clin Cardiol. 2007; 12(1):5-10.

13. Arranz S, Chiva-Blanch G, ValderasMartínez P, Medina-Remón A, Lamuela-Raventós RM, Estruch 
R. Wine, beer, alcohol and polyphenols on cardiovascular disease and cancer. Nutrients. 2012;4(7):759-781.

14. Gresele P, Pignatelli P, Guglielmini G, Carnevale R, Mezzasoma AM, Ghiselli A, et al. Resveratrol, at concentrations attainable with moderate wine consumption, stimulates human platelet nitric oxide production. J Nutr. 2008; 138(9):1602-1608.

15. Apostolidou C, Adamopoulos K, Lymperaki E, Iliadis S, Papapreponis P, KourtidouPapadeli C. Cardiovascular risk and benefits from antioxidant dietary intervention with red wine in asymptomatic hypercholesterolemics. Clin Nutr ESPEN. 2015; 10(6):e224-33.

16. Karatzi K, Papamichael C, Aznaouridis $\mathrm{K}$, et al. Constituents of red wine other than alcohol improve endothelial function in patients with coronary artery disease. Coron Artery Dis. 2004;15(8): 485-490.

17. Hansen AS, Marckmann P, Dragsted LO, Finné Nielsen IL, Nielsen SE, Grønbæk M. Effect of red wine and red grape extract on blood lipids, haemostatic factors, and other risk factors for cardiovascular disease. Eur J Clin Nutr. 2005;59(3):449-55.

18. Filho PRS, Castro I, Stahlschmidt A. Effect of red wine associated with physical exercise in the cardiovascular system of spontaneously hipertensive rats. Arq Bras Cardiol. 2011;96(4): 277-82.

19. Whelan AP, Sutherland WHF, McCormick MP, Yeoman DJ, De Jong SA, Williams MJA. Effects of white and red wine on endothelial function in subjects with coronary artery disease. Intern Med J. 2004;34(5):224-8.

20. Lekakis J, Rallidis LS, Andreadou I, Vamvakou G, Kazantzoglou G,
Magiatis P, et al. Polyphenols compounds from red grapes acutely improve endothelial function in patients with coronary heart disease. Eur J Cardiovasc Prev Rehabil. 2005;12(6):596-600.

21. Karatzi KN, Papamichael CM, Karatzis EN, Papaioannou TG, Aznaouridis AK, Katsichti PP, et al. Red wine acutely induces favorable effects on wave reflections and central pressures in coronary artery disease patients. Am J Hypertens 2005;18(9):1161-7.

22. Ceriello A, Bortolotti N, Motz E, Lizzio S, Catone B, Assaloni R, et al. Red wine protects diabetic patients from meal-induced oxidative stress and thrombosis activation: A pleasant approach to the prevention of cardiovascular disease in diabetes. Eur $\mathbf{J}$ Clin Invest. 2001;31(4):322-8.

23. Guarda E, Godoy I, Foncea R, Perez DD> Romero C, Venegas R, et al. Red wine reduces oxidative stress in patients with acute coronary syndrome. Int J Cardiol. 2005; 104(1):35-8.

24. Avellone G, Di Garbo V, Campisi D, De Simone R, Raneli G, Scaglione $\mathrm{R}$, et al. Effects of moderate Sicilian red wine consumption on inflammatory biomarkers of atherosclerosis. Eur J Clin Nutr. 2006;60(1):41-7.

25. Zern TL, Fernandez ML. Recent Advances in Nutritional Sciences Cardioprotective Effects of Dietary. 2005;(February):2291-4.

26. Gomikawa S, Ishikawa Y, Hayase W, Haratake Y, Hirano N, Matuura H, et al. Effect of ground green tea drinking for 2 weeks on the susceptibility of plasma and LDL to the oxidation ex vivo in healthy volunteers. Kobe J Med Sci. 2008;54(1):62-72.

27. Hardani E, Lestariana W, Susetyowati S. Efek pemberian ekstrak teh hijau (Camellia sinesis (L) O. 
Kuntze) var. Assamica terhadap total lemak tubuh dan profil lipid wanita dewasa overweight dan obesitas. J Gizi Klin Indones. 2014;10(4):209.

28. Agewall S, Wright S, Doughty RN, Whalley GA, Duxbury M, Sharpe N. Does a glass of red wine improve endothelial function? Eur Heart J. 2000;21(1):74-78.

29. Hashimoto M, Kim S, Eto M, Iijima K, Ako J, Yoshizumi M, et al. Effect of acute intake of red wine on flow-mediated vasodilatation of the brachial artery. Am J Cardiol. 2001;88(12):1457-60.

30. Goldberg DM, Yan J, Soleas GJ. Absorption of three wine-related polyphenols in three different matrices by healthy subjects. Clin Biochem. 2003;36(1):79-87.

31. Manach C, Mazur A, Scalbert A. Polyphenols and prevention of cardiovascular diseases. Curr Opin Lipidol. 2005;16(1):77-84.

32. Alexopoulos N, Vlachopoulos C, Aznaouridis $\mathrm{K}$, et al. The acute effect of green tea consumption on endothelial function in healthy individuals. Eur J Prev Cardiol. 2008;15(3):300-5.
33. Lorenz M, Rauhut F, Hofer C, Gwosc S, Muller E, Praeger D, et al. Teainduced improvement of endothelial function in humans: No role for epigallocatechin gallate (EGCG). Sci Rep. 2017;7(1):1-10.

34. Steptoe A, Gibson EL, Vuononvirta R, Hamer M, Wardle J, Rycroft JA, et al. The effects of chronic tea intake on platelet activation and inflammation: A double-blind placebo controlled trial. Atherosclerosis. 2007;193(2):77282.

35. Jochmann N, Lorenz M, von Krosigk A, Martus P, Bohm V, Baumann G, et al. The efficacy of black tea in ameliorating endothelial function is equivalent to that of green tea. Br J Nutr. 2008;99(4):863-8.

36. Peng X, Zhou R, Wang B, Yu X, Yang $X$, Liu $K$, et al. Effect of green tea consumption on blood pressure: A meta-analysis of 13 randomized controlled trials. Sci Rep. 2014;4(September).

37. $\mathrm{Xu} \mathrm{R}$, Yang K, Ding J, Chen G. Effect of green tea supplementation on blood pressure. Medicine (Baltimore). 2020;99(6):e19047. 